\title{
Megaspores from the Lower Jurassic (Pliensbachian) Rotzo Formation (Monti Lessini, northern Italy) and their palaeoenvironmental implications
}

\author{
Mirco Neri ${ }^{1} \cdot$ Evelyn Kustatscher ${ }^{2,3}$ (D) $\cdot$ Guido Roghi $^{4}$
}

Received: 15 May 2017 / Revised: 26 September 2017 / Accepted: 16 November 2017 / Published online: 16 February 2018

(C) The Author(s) 2018. This article is an open access publication

\begin{abstract}
The Rotzo Formation is famous for its Lower Jurassic terrestrial flora and marine (invertebrate) and terrestrial (dinosaur footprint) fauna. However, lycophyte macrofossils were never described from this time period in Italy, although palynological analyses yielded abundant lycophyte spores. Dispersed megaspores, in association with charcoal and amber drops, were recently collected from several horizons and outcrops of the Monte Lessini area. Sedimentological and palaeontological data reconstruct the palaeoenvironment as a paralic swamp under a warm and humid (monsoonal) climate. This is the first record of Jurassic megaspores from Italy, increasing our understanding of Jurassic lycophyte diversity, since at least five microspore and five megaspore genera with selaginellalean botanical affinities can be distinguished. Moreover, this underlines how well these brackish environments were adapted for the preservation of fossil plant remains (including amber).
\end{abstract}

This article is a contribution to the special issue "Jurassic biodiversity and terrestrial environments"

Evelyn Kustatscher

evelyn.kustatscher@naturmuseum.it

Mirco Neri

mirco.lias@gmail.com

Guido Roghi

guido.roghi@igg.cnr.it

1 Department of Chemical and Geological Sciences, University of Modena and Reggio Emilia, Via Campi 103, 41125 Modena, Italy

2 Museum of Nature South Tyrol, Bindergasse/via Bottai 1, 39100 Bolzano, Italy

3 Department für Geo- und Umweltwissenschaften, Paläontologie und Geobiologie, Ludwig-Maximilians-Universität, Bayerische Staatssammlung für Paläontologie und Geologie, Richard-Wagner-Straße 10, 80333 München, Germany

4 Institute of Geosciences and Earth Resources (IGG-CNR), Via Gradenigo 6, 35131 Padova, Italy
Keywords Lycophytes $\cdot$ Mesofossils $\cdot$ Palynomorphs $\cdot$ Plant remains $\cdot$ Palaeoenvironmental reconstructions

\section{Introduction}

The most famous Early Jurassic (Pliensbachian) flora of Italy comes from the Rotzo Formation (Grey Limestone Group), a thick succession of shallow-water carbonates cropping out in the western Veneto and Trentino regions (eastern Southern Alps). Plant fossils have been known from these successions since 1764 (Dal Pozzo 1820), but they became famous following the studies of Baron Achille De Zigno (1850, 1852, 1856-1868, 1865a, 1865b, 1868, 1872, 1878, 1873-1885) and Abramo Massalongo (1853a, 1853b, 1851, 1856, 1859). De Zigno described in his 'Flora fossilis formationis oolithicae' (De Zigno 1856$1868,1873-1885) 326$ species, 82 of which were described for the first time. The third and last volume (conifers), however, was never published due to his death in 1892 (for more details see Grandori 1913a, b, 1915; Wesley 1956). A revision carried out by Wesley (1956, $1958,1966,1973,1974)$ reduced the number of species to 67 including sphenophytes (e.g. Phyllotheca), ferns (e.g. Gleichenites, Dictyophyllum, Coniopteris, Phlebopteris, Matonidium), seed ferns (Sagenopteris, Pseudosagenopteris, Cycadopteris, Dichopteris), cycadophytes (e.g. Sphenozamites, Otozamites, Ptilophyllum, Weltrichia) and conifers (e.g. Brachyphyllum, Pagiophyllum, Elatocladus). Ginkgophytes and lycophytes, two groups well known from Jurassic floras, were, however, never described from this flora.

What makes the absence of lycophyte macrofossils from the Lower Jurassic of the Southern Alps even more peculiar is the fact that lycophyte spores (e.g. Densosporites, Foveosporites, Lycopodiacidites, Retitriletes, Retusotriletes, 
Uvaesporites) are well represented in the palynological record from the Rotzo Formation (van Erve 1977; Avanzini et al. 2006; Neri et al. 2016). This lack of lycophyte macrofossils could be related to the fragile nature of these plants inhibiting their preservation as fossils or it could be linked to unfavourable environmental conditions, meaning that these plants were rare elements of the flora (Batten 1974; Skog and Hill 1992; Kovach and Batten 1993; Slater et al. 2015; Slater and Wellman 2015, 2016). A recently discovered outcrop near Bellori village (Verona Province) yielded not only amber, bivalves, foraminifers, solitary corals, ostracods and carbonised wood (Neri et al. 2016) but also several types of megaspores supporting the former theory.

Most Jurassic megaspores are attributed to the lycophyte orders Isoetales and Selaginellales, but are rarely studied in the palynological assemblages because of their low frequency (e.g. McLoughlin et al. 2014). Despite this apparent dearth of material, they are abundant in many Mesozoic mesofossil assemblages from all over the world (e.g. Batten and Kovach 1990; Scott and Playford 1985; Wierer 1997, 1999; McLoughlin et al. 2014). Mesozoic megaspores from Europe have been studied also in correspondence with important stratigraphic successions such as the Upper Triassic St. Cassian Formation of the Dolomites (northern Italy; e.g. Wierer 1997, 1999) or in situ in lycophyte strobili from the Triassic of Europe (e.g. Lundblad 1950; Zavialova et al. 2010; Van Konijnenburg-van Cittert et al. 2014, 2016), among others. The aim of this paper is to describe for the first time megaspores from the Jurassic of Italy and to increase our understanding of the diversity of lycophytes during the Jurassic in Europe. Moreover, the presence of megaspores gives us important insights into the floral composition and the palaeoenvironments of the Jurassic of the Southern Alps.

\section{Geological and palaeogeographic setting}

During the Jurassic, northeastern Italy was characterised by the Trento Platform, a palaeo-high confined by the Belluno Basin to the east and Lombardy Basin to the west (Bosellini et al. 1981; Winterer and Bosellini 1981; Masetti et al. 1998; Neri et al. 2016). The Trento Platform corresponds today to an area that extends from Verona to the Dolomites (northsouth direction) and from Monte Grappa to Lake Garda (eastwest direction) (Masetti et al. 2012). The Trento Platform represents one of the most important palaeogeographic units of the passive margin on the southern side of the northern Pangea Branch (Masetti et al. 1998). This area was characterised by horst and graben structures inherited from the Early Jurassic rifting phase associated with the opening of the central North Atlantic Ocean.
The Jurassic succession of the Trento Platform is divided into two main stratigraphic sequences, the shallow marine Calcari Grigi-Oolite di San Vigilio Groups (Hettangian-Pliensbachian) and the pelagic Rosso Ammonitico Veronese (upper Bajocian-Tithonian) (Barbieri and Grandesso 2007; Masetti et al. 2012). The Calcari Grigi Group (former Calcari Grigi Formation; Bosellini and Broglio Loriga 1971) is divided into three units, the Monte Zugna Formation (HettangianSinemurian), the Loppio Oolitic Limestone (SinemurianPliensbachian) and the Rotzo Formation (Pliensbachian) (Castellarin et al. 2005; Masetti et al. 2012). The various formations ( $>200 \mathrm{~m}$ thick in total) have a good lateral continuity over the entire Trento Platform.

The Rotzo Formation is vertically and laterally characterised by a series of diverse and highly variable facies due to the influence of the palaeogeography and sea-level fluctuations. The westernmost sector (Monte Baldo and Adige River area) is mainly characterised by marginal oolitic shoals. The typical facies of the Rotzo Formation are ooidal, peloidal, bioclastic and intraclastic limestones with marly and clayey horizons rich in plant remains and thin coal levels (Broglio Loriga and Neri 1976; Boomer et al. 2001; Roghi and Romano 2008; Posenato and Masetti 2012). Macrofossils are common and include molluscs (large and small bivalves such as Lithiotis s.l.), gastropods, brachiopods, corals, echinoderms and plant remains (De Zigno 1856-1868, 1873-1885; Wesley 1956, 1958). Microfossils consist mainly of foraminifera (mostly benthic agglutinated, rare lamellar and porcelaneous-walled species), algae (e.g. Thaumatoporella parvovesiculifera) and ostracods (e.g. Phraterfabanella tridentinensis), although foraminifera are locally rare (Bosellini and Broglio Loriga 1971; Fugagnoli and Loriga Broglio 1998; Boomer et al. 2001). The lower part of the Rotzo Formation yielded also a rich palynoflora including Ischyosporites variegatus (Couper) Schulz, 1967 , Leptolepidites major Couper, 1953, Matonisporites crassiangulatus Levet-Carette, 1964, and Trilites lygodioides Mai, 1967, that was previously attributed to the Toarcian (Schulz 1967), but is now known to extend to the Sinemurian-Pliensbachian (Avanzini et al. 2006). Recently, Neri et al. (2016) described the first amber from this formation. The Rotzo Formation has been dated, based on foraminifera, ammonites, green algae and isotopic analyses $\left({ }^{13} \mathrm{C}\right.$ and ${ }^{87} \mathrm{Sr} /{ }^{86} \mathrm{Sr}$ ), to the Pliensbachian (Avanzini et al. 2006; Fugagnoli 2004; Posenato and Masetti 2012; Franceschi et al. 2014).

\section{Material and methods}

The megaspores were collected from three outcrops in the Lessini Mountains (Fig. 1), the Bellori outcrop, Ponte 
Fig. 1 Geographical distribution of the outcrops yielding megaspores: (1) Bellori, (2) Ponte Basaginocchi and (3) Vajo dell'Anguilla. The lines indicate river and streams

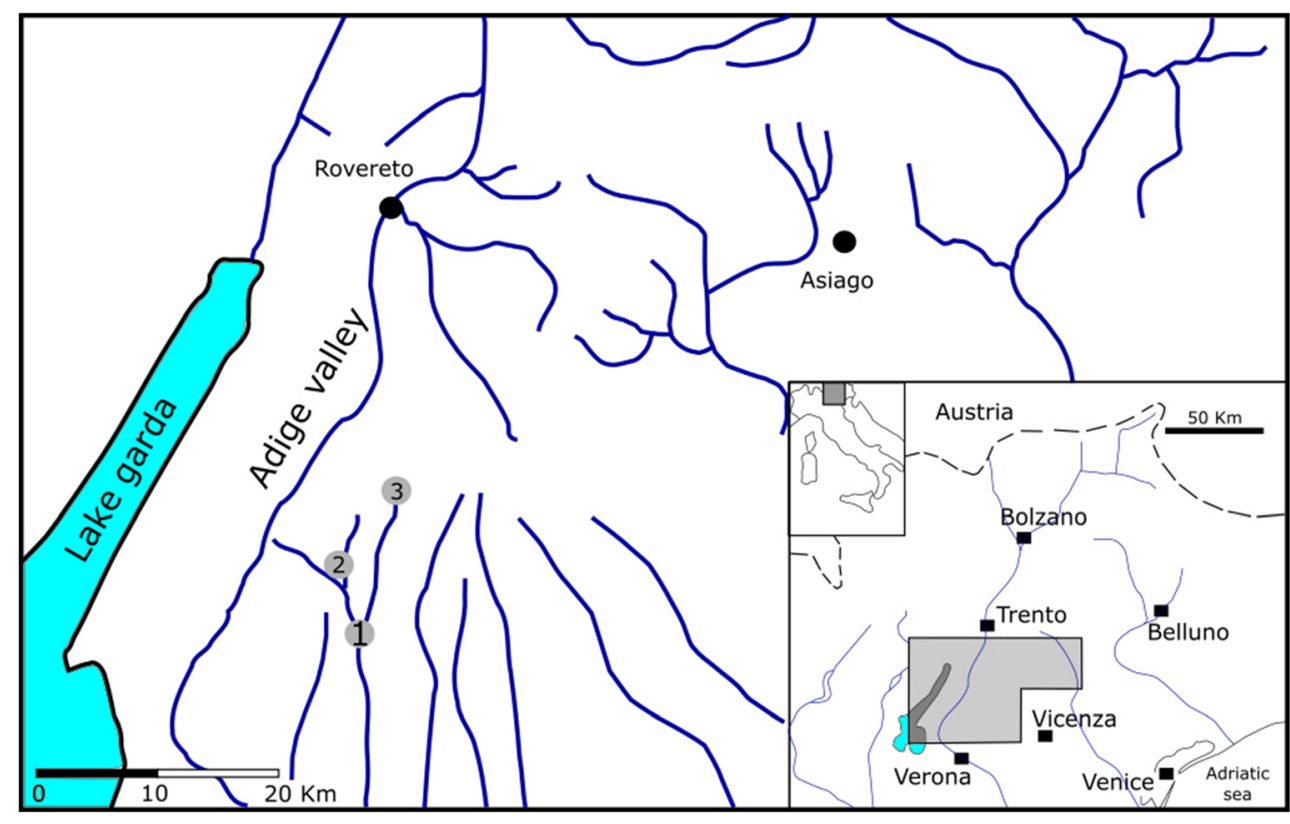

Basaginocchi outcrop and Vajo dell'Anguilla outcrop. The first outcrop is in a quarry near Bellori village in the Grezzana municipality (Verona Province; N $45^{\circ} 35^{\prime} 48.6^{\prime \prime}$, E $\left.10^{\circ} 59^{\prime} 48.0^{\prime \prime}\right)$. The exposure, which is about $25 \mathrm{~m}$ thick, yielded the first Lower Jurassic amber of Italy (Neri et al. 2016). The strata are composed of grey-bluish limestone (yellow when weathered; $0.1-1 \mathrm{~m}$ thick), well stratified, alternating with dark clayey/marly layers (3-4 cm thick) rich in organic matter including coal layers (Fig. 2). Layer $\mathrm{C} 1$ is thicker $(\sim 40 \mathrm{~cm})$ and contains a prominent coal level. The limestones yielded abundant bivalves, belonging to the characteristic gregarious bivalve genus Lithiotis, foraminifers, brachiopods, gastropods, ostracods, bryozoans, echinoids and green algae. Layer C3 is characterised by fossil roots, indicating an interval of emergence. The alternation of limestones and clayey/marly layers suggests cyclical variations in the relative sea level. Foraminifera assign the lower middle portion of the stratigraphic section to the lower Pliensbachian (Orbitopsella zone), whereas the upper part belongs to the upper Pliensbachian (Neri et al. 2016). The megaspore-bearing layers can, thus, be dated confidently as early Pliensbachian. The megaspores of the Bellori outcrop come from two dark grey-black clayey-carbonaceous layers that are very rich in organic matter. About $2 \mathrm{~kg}$ of loose sediment was collected from the coal layer $\mathrm{C} 1$ and about $1 \mathrm{~kg}$ of loose sediment from the clayey-carbonaceous layer C4 (Fig. 2).

The Ponte Basaginocchi outcrop is situated along the road between Bellori and Erbezzo in the Sant'Anna d'Alfaedo Municipality (Verona Province; N 45 36' 34.09", E $10^{\circ} 58^{\prime}$ $29.40^{\prime \prime}$ ). The studied exposure of this outcrop (about $15.5 \mathrm{~m}$ ) is composed mainly of well-stratified yellow to grey-bluish limestone (Clari 1975). Both in the basal and in the upper part of the studied section, oolitic limestones are intercalated with bivalve limestones, and the latter alternate with some clayey $(3-10 \mathrm{~cm})$ and rare marly layers. The limestones of the central part of the section are rich in bivalves (Lithiotis), oncoids, foraminifers, brachiopods and gastropods. The layer PB5a is characterised by fossil roots, indicating an interval of emergence (Fig. 2). The samples from the Ponte Basaginocchi outcrop come from a clayey layer called PB6 (about $1 \mathrm{~kg}$ of loose sediment). The layer PB6M probably is the same layer recognised by Clari (1975) at about $40 \mathrm{~m}$ in his section.

The Vajo dell'Anguilla outcrop is situated near the Ponte di Vajo along the road between Bosco Chiesanuova and Erbezzo in the Erbezzo Municipality (Verona Province; N 45 39' $\left.33.75^{\prime \prime}, \mathrm{E} 11^{\circ} 00^{\prime} 56.05^{\prime \prime}\right)$. The section is about $3 \mathrm{~m}$ thick and predominantly composed of Lithiotis limestones alternated (every $10-15 \mathrm{~cm}$ ) with more clayey horizons that are richer in organic matter. The studied clayey layer is $10-15 \mathrm{~cm}$ thick and sits on top of a 80-cm-thick Lithiotis bank (Fig. 2), along the stream near the pathway to Vajo dell'Anguilla close to the section studied by Clari (1975) and Posenato and Masetti (2012). The samples (about $2 \mathrm{~kg}$ of loose sediment) from the Vajo dell'Anguilla outcrop come from an organic-rich horizon called VA1 containing Lithiotis, solitary corals, ostracods, coal fragments and amber. The amber in the VA1 layer appears similar to that in Neri et al. (2016), as it is constituted by thousands of thin filaments.

The collected sediment samples were washed and sieved in the laboratory of the University of Modena and Reggio Emilia, screened and analysed under a stereoscope 


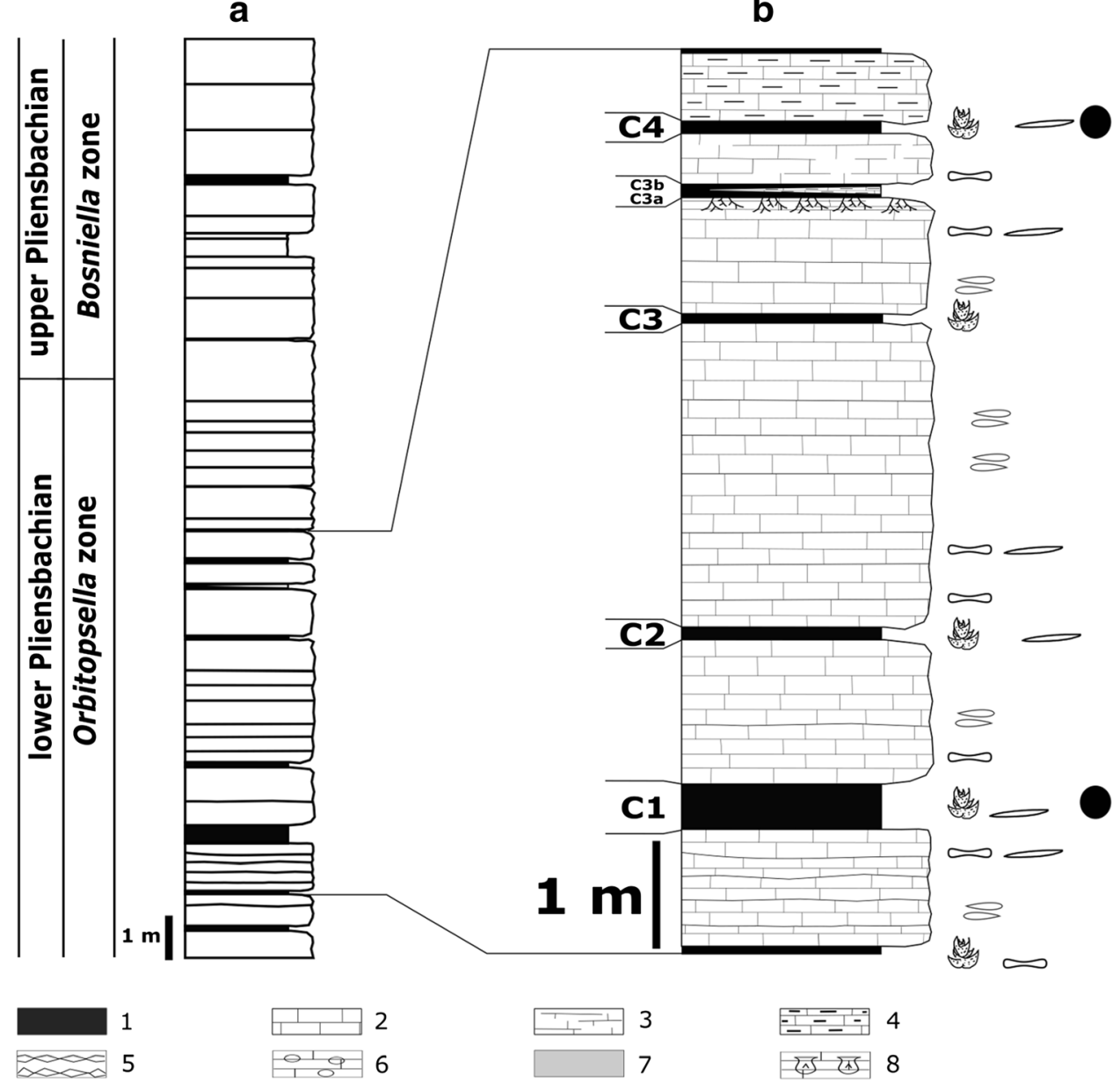

b c

\section{c}

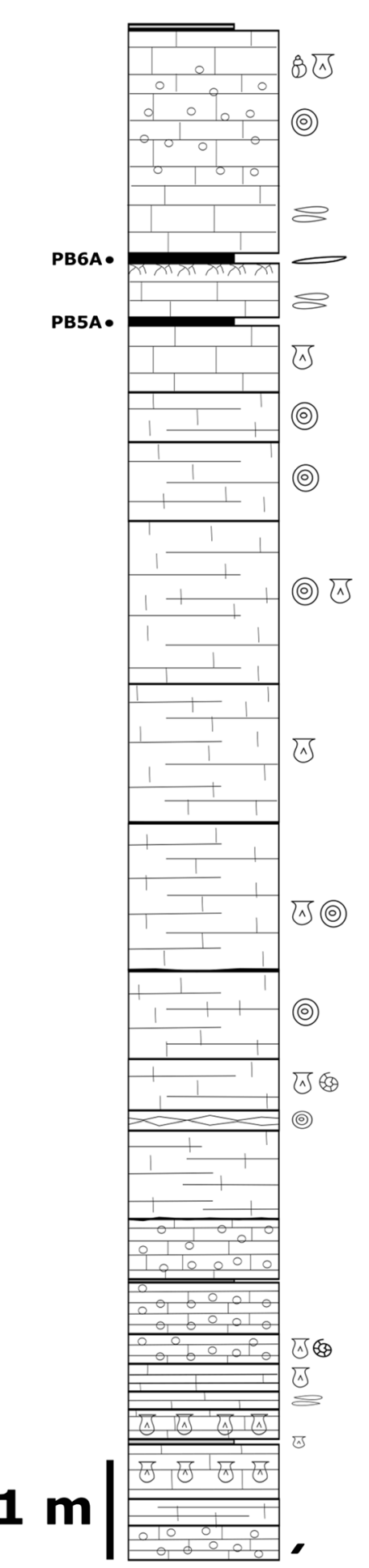

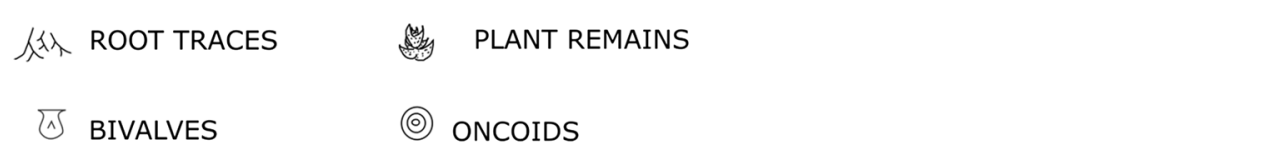

$œ$ Orbitopsella sp.

(8) GASTROPODS

AMBER

COAL FRAGMENTS

\section{(3) FORAMINIFERS \\ $\&$ Lithiotis BANK \\ Lithiotis s.l.}

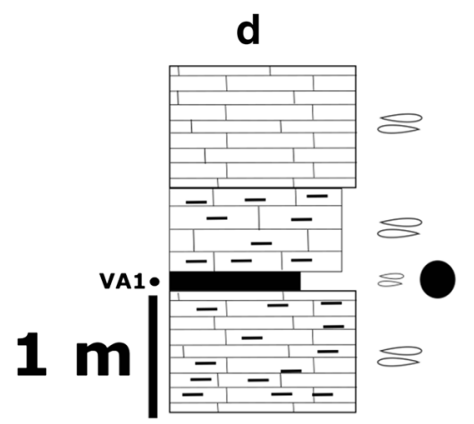

(2) grey to yellow massive limestone; (3) fine-grained limestone; (4) marly limestone; (5) nodular limestone; (6) oolithic limestone; (7) marl; (8) bivalve bank

housed at the Department of Chemical and Geological Sciences of the University of Modena and Reggio Emilia. 


\section{Systematic palynology}

Trileites Erdmann ex Potonié, 1956

Trileites sp. cf. Trileites murrayi (Harris) Marcinkiewicz, 1971

Fig. 3a-b; Fig. 5a-b

Description: Megaspores are spherical, sometimes flattened through compaction, 320-840 $\mu \mathrm{m}$, with the largest being about $1100 \mu \mathrm{m}$ in diameter ( $\sim 15$ specimens). The amb is circular; the laesurae are straight or weakly sinuous at the pole, extending for at least one third of the radius. Each side of the trilete opening is slightly increased by a low ridge, which brings the tetrad scar out in relief. The contact areas are laevigate, flat and sometimes slightly sunken and delimited only in a few specimens by weakly defined arcuate ridges, although true ridges are not developed (Fig. 3b). Distal and proximal surfaces of the exine are laevigate; the spore wall (exine) is about $40 \mu \mathrm{m}$ thick with a finely porous to spongelike internal structure.

Remarks: These megaspores fall within the lower part of the size range of this species $(250-1400 \mu \mathrm{m}$, mean of $830 \mu \mathrm{m})$. Similar laevigate or delicately granulate megaspores have been assigned to a broad range of species of the genera Trileites Erdmann ex Potonié, 1956 and Banksisporites Dettmann, 1961. Since a partially detached internal mesospore is not visible in our specimens, we assign them to Trileites rather than Banksisporites. The lack of distinctive morphological characters makes it difficult to assign the spores to any species with confidence. However, the trilete mark with a delicate rim and the generally smooth surface permits us to assign these specimens tentatively to the species Trileites murrayi (Harris) Marcinkiewicz, 1971. Harris (1961) observed a wide size range of small-, normal- and large-sized spores in many Yorkshire localities which he included however within one single species because of the continuity between the various grain sizes. In smaller specimens, the trilete mark is nearly as long as in normal megaspores, occupying, thus, a larger fraction of the spore radius. Harris (1961) suggested that the small spores were rather starved and aborted at different stages of growth, whereas David Batten has suggested that they are likely to belong to a different species (pers. comm. July 2017). Due to the fact that a wide range of dimensions was observed also for in situ spores of Selaginellites hallei Lundblad, 1950 and Triletes pinguis (Harris) Potonié, 1956 (Lundblad 1950) and because the number of specimens collected from the Southern Alps is reduced (few specimens), we assign our specimens for the moment to this species.

Distribution: Trileites murrayi is well known from the Jurassic of England, Denmark, Poland, Russia and China and Late Cretaceous of Sweden and the Netherlands (Gry 1969; Marcinkiewicz 1971, 1980; Yang 1982; Batten et al. 1985; Collinson et al. 1985; Koppelhus and Batten 1989; Kovach and Batten 1989; Batten and Kovach 1990).
Verrutriletes van der Hammen, 1955 ex Potonié, 1956 emend. Binda et Srivastava, 1968

Verrutriletes sp. cf. Verrutriletes compostipunctatus (Dijkstra) Potonié, 1956

Fig. 3d-f; Fig. 5c-d

Description: Megaspores are spherical, typically $350 \mu \mathrm{m}$ in equatorial diameter $(\sim 30$ specimens $)$. The amb is circular to subtriangular; the laesurae are straight, extending for at least half of the radius up to the equator. Each side of the trilete opening is slightly elevated by a thickening, which brings the tetrad scar out in relief. The ornamentation is composed of semicircular to half-moon-shaped verrucae that are fused at their base giving rise to ridges. The contact areas are covered by smaller verrucae; curvaturae are not observed (Fig. 3f). Remarks: The species is divided into two units with roundish slightly bigger (Fig. 3d, f; 12 specimens) and smaller subtriangular specimens (Fig. 3e; 17 specimens). The limited number of observed specimens does not permit us to distinguish whether they belong to two different species; thus, they are for the moment assigned to the same species. Perhaps further material will reveal if more than one species of Verrutriletes was present during the Early Jurassic in the Southern Alps.

Distribution: This species is typical for the Cretaceous of Europe and Canada (Potonié 1956; Singh 1964; Batten 1988; Kovach and Batten 1989; Batten and Kovach 1990).

Cabochonicus Batten et Ferguson, 1987

Cabochonicus sp. cf. Cabochonicus carbunculus (Djikstra) Batten et Ferguson, 1987

Fig. $4 \mathrm{a}-\mathrm{b}$

Description: One megaspore fragment of $455 \times 350 \mu \mathrm{m}$ size shows some very characteristic ornamental features. The exoexine is covered by numerous irregularly scattered, roundish and apparently hollow gemmae on the surface, which is $20 \mu \mathrm{m}$ in diameter. The globose structures are dark orange to brownish in colour, verruca-sized and more or less densely packed without merging bases. These ornamentations appear to be concentrated in the equatorial and distal parts of the megaspore, whereas the proximal part is free of ornamentation (upper part in the picture). The 'unsculptured' surface of the megaspore is more or less smooth, sometimes also slightly punctate or roughened.

Remarks: Similar spherical and hollow structures were described in literature as not being elements of the original structure but evidence of either bacterial or fungal infection. Marcinkiewicz $(1978,1980)$ described, based on their size, hollow structure and of the smooth surface of the exine, Reymanella globosa Marcinkiewicz, 1979 attached to 


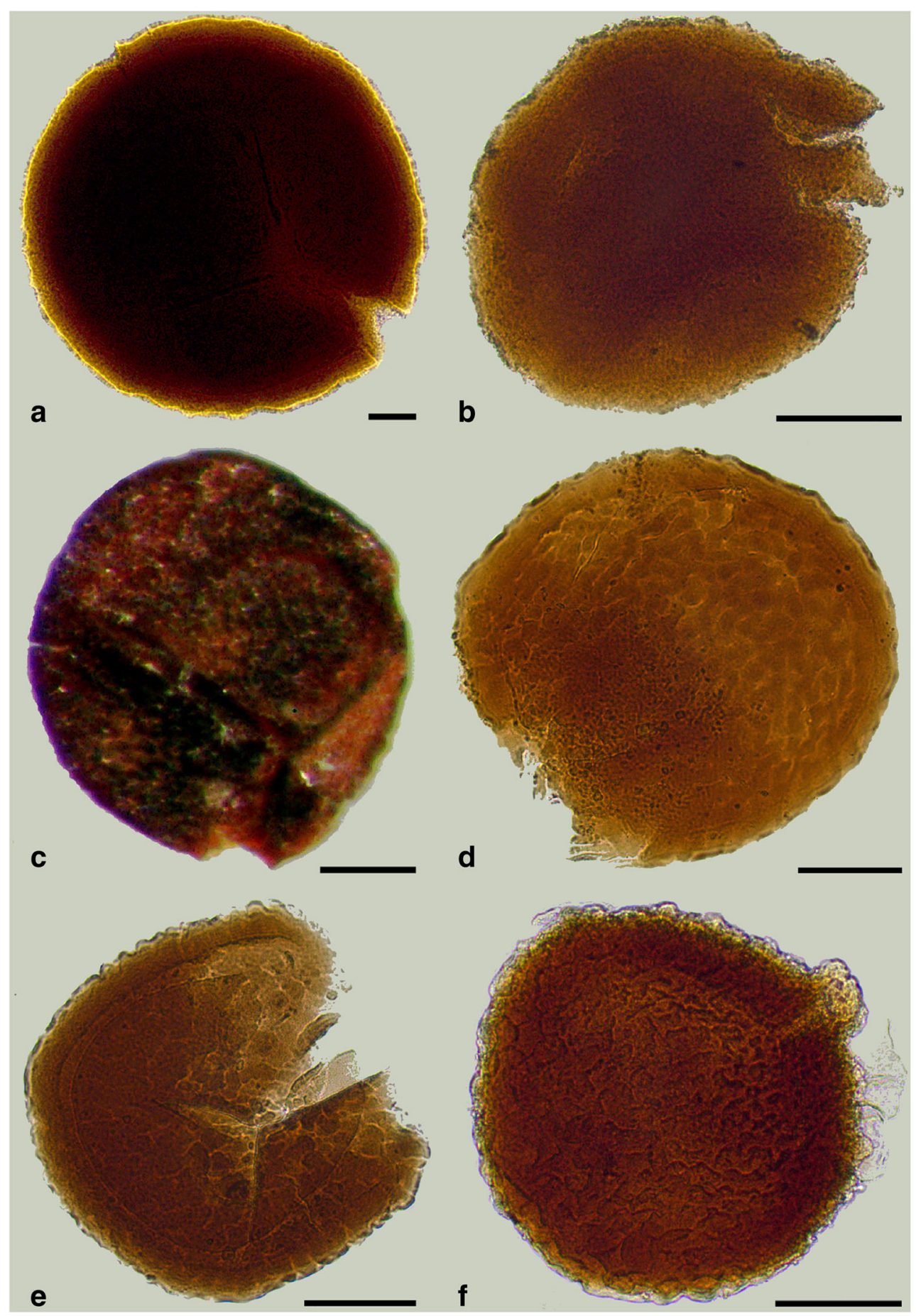

Fig. 3 Light micrographs of Jurassic megaspores of Italy. a-c Trileites sp. cf. Trileites murrayi (Harris) Marcinkiewicz, 1971, a is from C1 layer in Bellori; b, c are from PB6M layer from Ponte Basaginocchi; $\mathbf{d}-\mathbf{f}$

Verrutriletes sp. cf. Verrutriletes compostipunctatus (Dijkstra) Potonié, 1956, from PB6M layer from Ponte Basaginocchi. Scale bars $=100 \mu \mathrm{m}$

Trileites murrayi from the Lower Jurassic of Poland. Since we cannot observe any undisputable attachment structures of fungal origin, we prefer to assign our specimen tentatively to the species Cabochonicus carbunculus. Batten and Ferguson (1987) excluded the possibility that the verrucate structure could be related to fungal attach due to their TEM analyses.
They concluded that the sculpture of their specimens consisted of exinal excrescences. Also similar are the megaspores described as Verrutriletes imitatus (Dijkstra) Waksmundzka, 1982 and Verrutriletes guttatus Waksmundzka, 1982 from the Lower Cretaceous of Poland which were attributed by Batten and Ferguson (1987) to the same genus. 


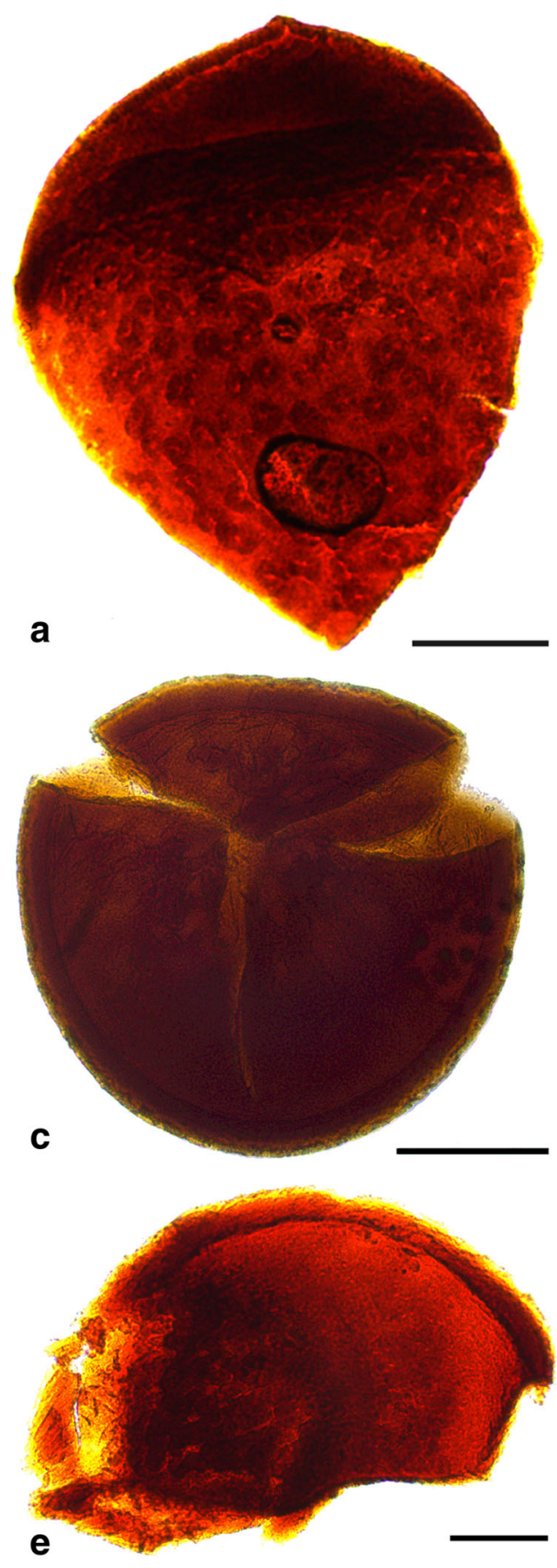

Fig. 4 Light micrographs of Jurassic megaspores from Italy. a, b Cabochonicus sp. cf. Cabochonicus carbunculus (Djikstra) Batten et Ferguson, 1987; from PB6M layer from Ponte Basaginocchi; c-f

The ultrastructure analyses suggest for this species a selaginellalean affinity. Batten and Ferguson (1987) suggested that the tendency for the genus to occur only sporadically and in low numbers in the sediments could be related to the drier habitat colonised by the mother plants.

Distribution: Cabochonicus carbunculus (Dijkstra) Batten et Ferguson, 1987 is well known from the Lower Jurassic of China and from the Cretaceous of Europe and the USA
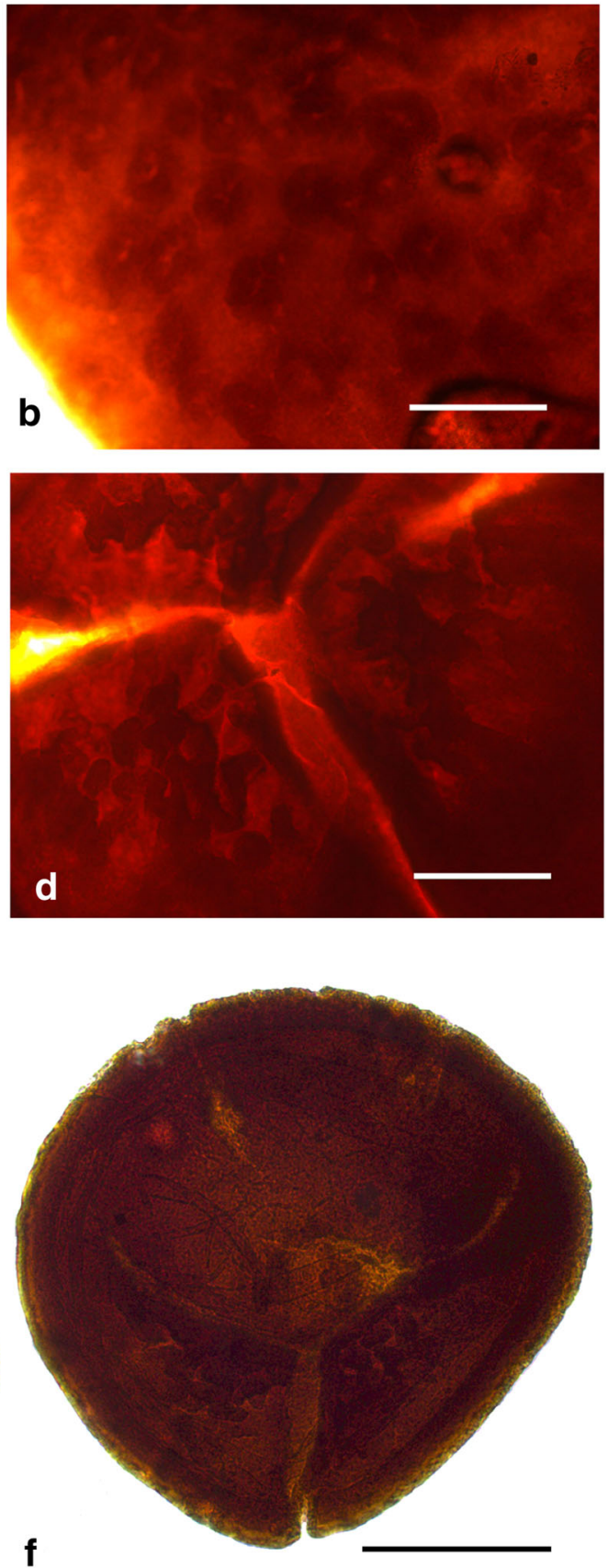

Hughesisporites sp. cf. Hughesisporites orlowskae Kozur, 19734; c, d, f from PB6M layer from Ponte Basaginocchi; e from VA1 layer from Vajo dell'Anguilla. Scale bars $=100 \mu \mathrm{m}$

(Potonié 1956; Batten 1974; Antonescu 1978; Hueber 1982; Collison et al. 1985; Kovach and Batten 1989; Batten and Kovach 1990). Batten and Ferguson (1987) considered its range to be from the late Rhaetian to the Santonian.

Horstisporites Potonié, 1956

Horstisporites harrisii (Murray) Potonié, 1956

Fig. $5 \mathrm{e}-1$ 
Description: Megaspores are subspherical, $320-500 \mu \mathrm{m}$ in equatorial diameter $(\sim 30$ specimens $)$. The amb is circular to subtriangular. The ridges of the trilete mark are straight to slightly sinuous, reaching almost two thirds of the spore radius; curvaturae are difficult to observe. The margins of the trilete mark are slightly thickened, which brings the tetrad scar out in relief. The ornamentation is composed of meandering, irregular to straight (rarer) ridges or tubercles with open ends. The ridges tend to form an irregular reticulum, with sometimes slightly thickened crossing points. The contact areas are covered by smaller tubercules with less tendency to form a reticulum, sometimes almost delicately verrucate (Fig. $5 \mathrm{~h}$ ). Spore wall is always thick, up to $20 \mu \mathrm{m}$. When broken (Fig. 5f), intexine is visible with a finely granular wall.

Remarks: The specimens are slightly smaller than the mean diameter of $600 \mu \mathrm{m}$ of the type material but stay within the range of 400-600 $\mu \mathrm{m}$. The distinct imperfect reticulum and the fact that the reticulum tends to disappear, leading to a more tuberculate structure, permits to assign our specimens to Horstisporites harrisii.

Distribution: This species is well known from the Jurassic Yorkshire sediments (Morris and Batten 2016), where one of the most important Jurassic floras of Europe comes from (Harris 1961, 1964, 1969, 1979; Harris et al. 1974). The species is also well distributed in the Triassic of France, Rhaetian to Jurassic of North America, Europe and Asia and in the Cretaceous of Germany and North America (Gry 1969; Bergad 1974; Arjang 1975; Marcinkiewicz 1980; Taugourdeau-Lantz 1983, 1984; Yang 1986; Kovach and Batten 1989; Batten and Kovach 1990; Feist-Burkhardt et al. 2009).

Hughesisporites Potonié, 1956

Hughesisporites sp. cf. Hughesisporites orlowskae Kozur, 1973

Fig. 4c-f; Fig. $5 \mathrm{~m}-\mathrm{n}$

Description: Megaspores are spherical, with circular amb and $330-550 \mu \mathrm{m}$ in equatorial diameter ( 20 specimens). The laesurae are straight, two thirds to three fourths of the radius of the spore; curvaturae are almost invisible. The margins of the trilete mark are thickened and protrude from the surface. The distal and equatorial exoexine is smooth to slightly punctate. The proximal side is covered between the rays of the trilete mark with thick verrucae and spinae that are oriented radially in direction of the opening of the megaspore. The ornamentation elements are the highest and most prominent at the apex of the megaspore and decrease in size toward the equator.

Remarks: The ornamental elements on the proximal side of the megaspores are not protruding very strongly from the surface of the spore; thus, we assign our specimens only tentatively to this species.
Distribution: Hughesisporites orlowskae Kozur, 1973 has been described only from the Triassic of Germany and Poland (Kozur 1973; Marcinkiewicz 1978; Batten and Kovach 1990).

\section{Palaeoenvironmental considerations}

Climatic conditions during Early Jurassic times are believed to have been generally hot and humid, favourable for extensive growth of delicate herbaceous lycophytes with prostrate shoots such as Selaginellites-type plants and strongly hygrophytic plants such as Isoetites. Palynological assemblages from the Bellori section (Neri et al. 2016) are dominated by the fern spore Deltoidospora sp. (>50\%) indicating a good availability of freshwater, since spores need wet climate and water for their transport (Pedersen and Lund 1980; Lund and Pedersen 1985). Second in order of abundance is Classopollis sp. (>40\%), a cheirolepidiacean pollen with a wide environmental range, from dry to wet climate in coastal to upland areas (Kendall 1949; Chaloner 1962; Srivastava 1976). Characteristics for this assemblage are also the freshwater algae Botryococcus Kützing, 1849 and Pseudoschizaea Christopher, 1976. The well-preserved cuticles and the large size of wood fragments containing amber indicate that the transport was short before deposition. All these characteristics, together with the presence of thin coal layers, would suggest deposition in a swampy to marshy environment.

This would suggest that the xeromorphic characters of many dispersed cuticles (thick with sunken stomata) could be related more to an adaptation to physiological drought or the presence of salt-laden wind from the nearby sea than to a generally arid climate. Similar xeromorphic characters have been observed in the plants of the swampy environment yielding the Late Triassic (Carnian) flora of Lunz (Pott et al. 2008). The influence of the sea in the succession is also testified by the presence of coral fragments, bivalves, echinoids and foraminifera in the three studied outcrops. Also, the limestone bank with Lithiotis s.l. followed by layers of clay and coal (e.g. C4 in Fig. 2) could indicate the presence of stagnant water tables (Posenato and Masetti 2012), whereas the in situ roots and lignite lenses support presence of an autochthonous vegetation. The low diversity of the ostracod fauna and local absence of foraminifera in the beds $\mathrm{C} 1$ and $\mathrm{C} 4$ of the Bellori section support at least locally a stressed environment. The palaeoenvironment of Bellori has, therefore, been interpreted as a paralic swamp under freshwater influence (Neri et al. 2016).

Considering the close resemblance with the other two sections, a similar environment can be postulated also for Ponte Basaginocchi and Vajo dell'Anguilla. Lycophytes such as Selaginellales and Isoetales would be well adapted to live in such a swampy environment, since they require moisture for 


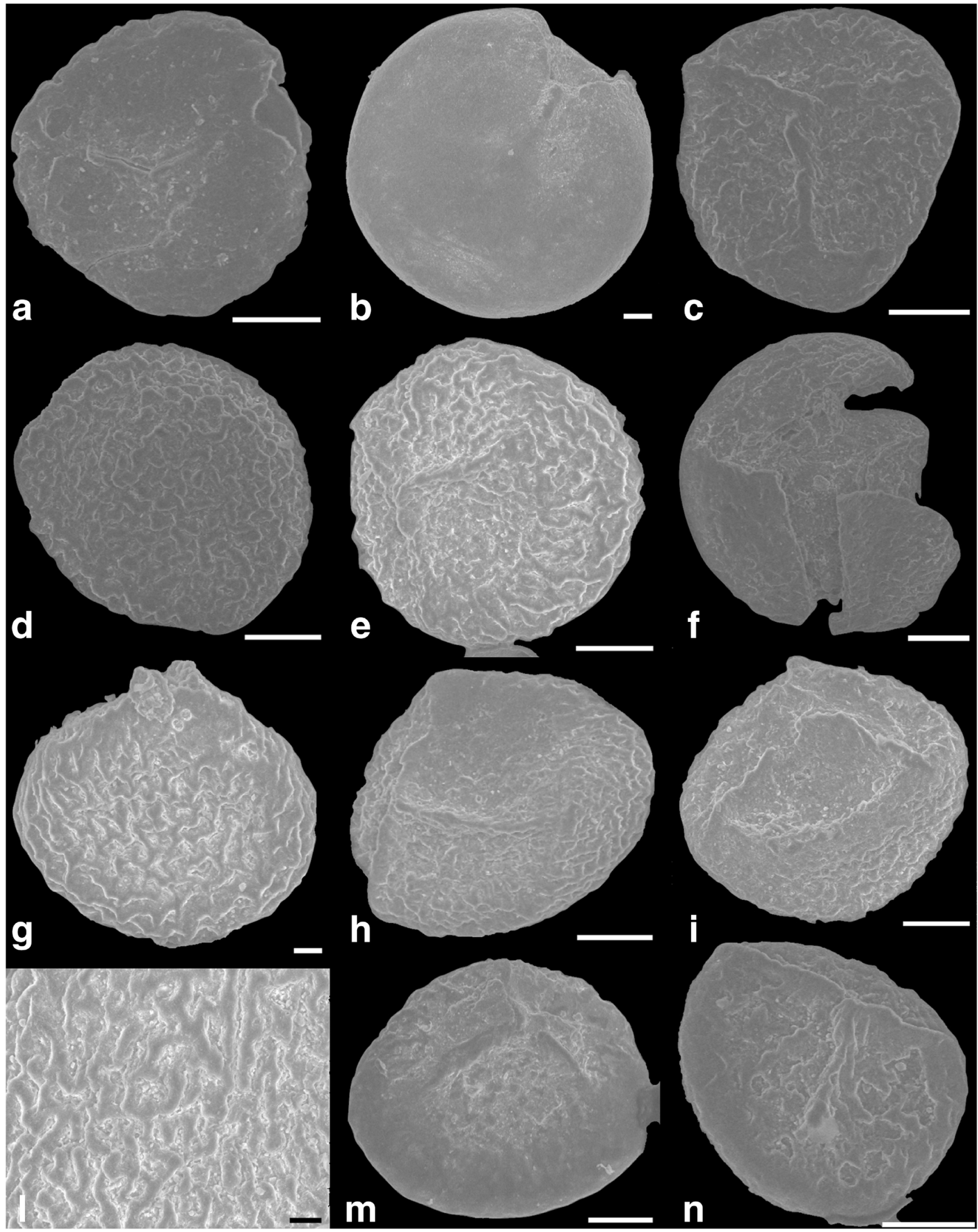

Fig. 5 SEM images of Jurassic megaspores of Italy. a, b Trileites sp. cf. Trileites murrayi (Harris) Marcinkiewicz, 1971; c, d Verrutriletes compostipunctatus (Dijkstra) (Potonié 1956); e-l Horstisporites harrisii (Murray) Potonié, 1956; m, n Hughesisporites sp. cf. Hughesisporites orlowskae Kozur, 19734; a, c-n from PB6M layer from Ponte Basaginocchi; $\mathbf{b}$ from C4 layer from Bellori. Scale bars $=100 \mu \mathrm{m}$ except in $\mathbf{g}$ and $\mathbf{I}$ where they equal to $30 \mu \mathrm{m}$ 
gamete exchange and tend to grow in consistently moist soils or even in semisubmerged to fully submerged conditions (Taylor et al. 2009). This is also evidenced by the abundance of megaspores. Small fragments of glossy black charcoal occurring in all studied samples indicate that fire was a consistent feature of the Early Jurassic landscape of the Southern Alps. The presence of some abraded and broken specimens among the charcoals and megaspores suggests reduced transport, but the majority of both megaspores and microspores have well-preserved ornamentation.

\section{Concluding remarks}

The Jurassic of Europe is greatly under-represented in terms of both number of recorded species and publications on Mesozoic megaspores compared to Triassic and Cretaceous sediments (e.g. Collinson et al. 1985; Kovach and Batten 1989). Moreover, so far, no megaspores have been recorded from the Jurassic of Southern Europe. This could also be due to the fact that the megaspores are indeed not that frequently preserved in the sediments, i.e. several kilogrammes of sediment from our three sections were washed in order to produce fewer than a hundred megaspores. Among the dispersed megaspores from the Bellori section, Trileites and Horstisporites are considered to belong to the Isoetales or Selaginellales (Batten 2012; Slater et al. 2015). Cabochonicus, Verrutriletes and Hughesisporites Potonié, 1956 are assigned to the Selaginellales (Batten and Ferguson 1987), mostly based on ultrastructure analyses (Slater et al. 2015). Trileites-type megaspores were found also in situ in Selaginellites polaris Lundblad, 1948 from the Lower Triassic of Greenland and in Pleuromeia sternbergii (Münster) Corda, 1852 from the Lower Triassic of Germany (Lundblad 1948; GrauvogelStamm and Lugardon 2004). Verrutriletes-type megaspores are known in situ from the Middle Triassic Isoetites brandneri Kustatscher et al., 2010 of Italy. Additional in situ megaspores from the Triassic-Jurassic of Europe are Banksisporites pinguis (Harris) Dettmann, 1961, later assigned to Triletes pinguis (Harris) Potonié, 1956, produced by Selaginellites hallei Lundblad, 1950 from the Rhaetian of Sweden and Tenellisporites-type megaspores extracted from Lepacyclotes zeilleri (Fliche) Retallack, 1997 emend. Kustatscher et al. 2015, an isoetalean lycophyte from the Ladinian of France (Kustatscher et al. 2015). Additional dispersed Mesozoic megaspore genera, which have not been reported in situ so far but are considered of selaginellalean origin because of their ultrastructure, are Thylakosporites Potonié, 1956, Erlansonisporites Potonié, 1956, Horstisporites Potonié, 1956, Rugotriletes van der Hammer, 1955 ex Potonié, 1956, Ricinospora Bergad, 1978 and Reticuspinosporites Slater et al., 2015 (Kovach 1994; Slater et al. 2015). The number of dispersed megaspore genera showing presumably selaginellalean and isoetalean features is, thus, much higher than the number of megaspores so far found in situ, showing that the diversity is much higher than is suggested by the macrofossils alone.

Among the dispersed lycophyte microspores from the Jurassic of the Southern Alps, on the other hand, are five genera that are traditionally considered to belong to the Selaginellales (Densoisporites, Foveosporites, Uvaesporites), Lycopodiales (Lycopodiacidites) or just generally to the lycophytes (Retusotriletes), based on their morphological resemblance to modern spores or to congeneric fossil spores (Dettmann 1986; Balme 1995; Raine et al. 2011; McLoughlin et al. 2014), but no typical isoetalean microspore taxon (e.g. Aratrisporites) has been recovered. Moreover, Isoetales live in or close to water bodies but generally in sweet-water environments (e.g. Kustatscher et al. 2010 and references therein), whereas the sediments studied in this paper were deposited in paralic swamps with freshwater influence, which would probably not be a typical environment for the growth of isoetalean plants. This would suggest that the megaspores from the three investigated sections of the Rotzo Formation were probably all produced by Selaginellales.

In this context, it is interesting to note that many TriassicJurassic Selaginellales (e.g. Selaginellites leonardii Kustatscher et al. 2015, Selaginellites coburgensis 2014) are reconstructed as small and fragile plants with few distinctive features and thus easily fragmented and destroyed by mechanical forces (Kustatscher et al. 2010; Van Konijnenburg-van Cittert et al. 2014, 2016). Consequently, their identification is difficult when the macrofossils are not exceptionally preserved (Skog and Hill 1992; McLoughlin et al. 2014). Moreover, the cuticles are, when preserved, extremely thin, similar to most extant forms (Kustatscher et al. 2010), suggesting that the species grew in protected habitats with ample water supply, such as the understorey of a dense forest, or intermingled with other herbaceous plants between rocks and close to bodies of water (Van Konijnenburg-van Cittert et al. 2014, 2016). This would suggest a higher preservation potential because of where they grew but the delicate structure of the plants themselves would make preservation more difficult. The delicate and easily detached and degraded leaves of lycophytes, together with the general similarity of leaf shapes belonging to various species within this plant group, could explain the lack or low diversity of lycophytes in the Jurassic macrofloras. However, local high abundance of lycophyte microspores in the Rotzo Formation suggests that the remains come from a confined source area, which would have been occupied by the lycophyte parent plants (cf. Slater and Wellman 2016). The higher diversity of lycophytes in sporomorph assemblages could be related also to epiphytic communities, since the latter are generally poorly represented in the megafossil record, as the burial and subsequent fossilisation of such forms is more unlikely than for other 
plants, whereas spores do not experience the same taphonomic bias (Slater and Wellman 2015, 2016 and references therein). The megaspore record reveals, thus, a greater diversity of plants than the macrofossils alone. A similar abundance and diversity in the megaspore but near lack in megafossil record in the same deposit have already been observed from the Middle Jurassic of Yorkshire (Harris 1961; Slater and Wellman 2015).

The fact that megaspores are associated in lignite deposits with amber drops and plant fragments with well-preserved cuticles alternated with clay layers rich in marine animals is not new in the Mesozoic of Europe. The Late Cretaceous amber from Vendée (northwestern France) was deposited in a mangrove to coastal marsh environment under a warm and wet (tropical) climate together with arthropods, crustaceans, foraminifera, dinoflagellates and few ostracods and a sporedominated palynoflora (Néraudeau et al. 2016). A similar fossiliferous composition has been observed also in some upper Turonian lignite deposits of Dordogne (SW France). The clays yielding several conifer and angiosperm remains, megaspores (Ariadnaesporites, Bacutriletes, Echitriletes, Erlansonisporites, Maexisporites, Minerisporites and Verrutriletes) and amber are overlain by lignitic sandstones with large fossil wood fragments, small solitary corals, bivalves, echinoids and marine fish remains. The megaspore-rich sediments have been attributed to a calm, estuarine to lagoonal environment (Néraudeau et al. 2016). Mid Cretaceous deposits in western France yielding amber, lignites, megaspores (Minerisporites, Paxillitriletes, Ariadnaesporites, Dijkstraisporites, Tenellisporites), a sporedominated palyno-assemblage, oysters, echinoids and vertebrate remains were likewise deposited in a lacustrine to paralic environment (Batten et al. 2010).

There are also sedimentary successions described from the Mesozoic of Europe that were deposited in similar environments but did not yet yield any megaspores. This includes the famous Late Triassic (Carnian) Lunz flora, deposited under conditions of a high groundwater table, reduced oxygen supply and low $\mathrm{pH}$ values, typical for swamps or peat bogs (Pott et al. 2008). The rich and diverse flora was found associated with amber drops and several coal horizons. The fact that no megaspores have been described so far may be related rather to a lack in targeted collecting effort than in the lack of preservation. Future collecting in these types of environments may increase our understanding of the diversity in megaspores notably.

Acknowledgements The authors thank Paolo Ferretti and Nicola Angeli from the MUSE in Trento for their kind help during the SEM analyses. An anonymous reviewer and David Batten are thanked for their constructive remarks during the review process. This paper is part of the UNESCO-IUGS IGCP Project 632 'Continental Crises of the Jurassic: Major Extinction Events and Environmental Changes within Lacustrine Ecosystems'. The authors thank the Department of Innovation, Research and University of the Autonomous Province of Bozen/Bolzano for covering the Open Access publication costs.

\section{Compliance with ethical standards}

Conflict of interest The authors declare that they have no conflict of interest.

Open Access This article is distributed under the terms of the Creative Commons Attribution 4.0 International License (http:// creativecommons.org/licenses/by/4.0/), which permits unrestricted use, distribution, and reproduction in any medium, provided you give appropriate credit to the original author(s) and the source, provide a link to the Creative Commons license, and indicate if changes were made.

\section{References}

Antonescu, E. (1978). Three new types of spores in the Triassic and Cretaceous of Roumania. [Trois nouveaux types de spores dans le Trias et le Cretace de Roumanie]. Revue de Micropaléontologie, 21(1), 3-12.

Arjang, B. (1975). Die räto-jurassischen Floren des Iran und Afghanistans. 1. Die Mikroflora der räto-jurassischen Ablagerungen des Kermaner Beckens (Zentral-Iran). Palaeontographica, Abteilung B, 152, 85148.

Avanzini, M., Pibelli, D., Mietto, P., Roghi, G., Romano, R., \& Masetti, D. (2006). Lower Jurassic (Hettangian-Sinemurian) dinosaur track megasites, Southern Alps, Northern Italy. In J.D. Harris, S.G. Lucas, J.A. Spielmann, M.G. Lockley, A.R.C. Milner, J.I. Kirkland (Eds.), The Triassic-Jurassic Terrestrial Transition (vol. 37, pp. 207-216). New Mexico: New Mexico Museum of Natural History and Science Bulletin.

Balme, B. E. (1995). Fossil in situ spores and pollen grains: an annotated catalogue. Review of Palaeobotany and Palynology, 87, 1-323.

Barbieri, G., Grandesso, P. (2007). Note Illustrative della Carta Geologica Italiana, 1:50.000, foglio Asiago. S.EL.CA, Firenze, 1135.

Batten, D. J. (1974). Wealden palaeoecology from the distribution of plant fossils. Proceedings of the Geologists' Association, 85(4), 433-458.

Batten, D. J. (1988). Revision of S. J. Dijkstra's Late Cretaceous megaspores and other plant microfossils from Limburg, the Netherlands. Mededelingen Rijks Geologische Dienst, Nieuwe Serie, 41(3), 1-55.

Batten, D. J. (2012). Implications of exospore structure in selected Mesozoic lycopsid megaspores. Palynology, 36(1), 144-160.

Batten, D. J., \& Ferguson, D. J. P. (1987). Cabochonicus, a new genus for species of gemmate megaspores previously referred to Verrutriletes. Journal of Micropalaeontology, 6(1), 65-75.

Batten, D. J., \& Kovach, W. L. (1990). Catalog of Mesozoic and Tertiary megaspores. American Association of Stratigraphic Palynologists, contributions Series number, 24, 1-227.

Batten, D.J., Creber G.T., Zhou Zhiyan (1985). Fossil plants and other organic debris in Cretaceous sediments from Deep Sea Drilling Project Leg 80. Their paleoenvironmental significance and source potential. Deep Sea Drilling Project, Washington, Initial Reports, (U.S. Gov't Print Office), 80(1), 629-641.

Batten, D. J., Colin, J.-P., \& Néraudeau, D. (2010). Megaspores from mid Cretaceous deposits in western France and their biostratigraphic and palaeoenvironmental significance. Review of Palaeobotany and Palynology, 161, 151-167. 
Bergad, R.D. (1974). Palynology of the Hell Creek Formation (Maastrichtian) in South-Central North Dakota. PhD Thesis, University of Minnesota.

Boomer, I., Whatley, R., Bassi, D., Fugagnoli, A., \& Loriga, C. (2001). An Early Jurassic oligohaline ostracod assemblage within the marine carbonate platform sequence 684 of the Venetian Prealps, NE Italy. Palaeogeography, Palaeoclimatology, Palaeoecology, 166, 331-344.

Bosellini, A., \& Broglio Loriga, C. (1971). I "Calcari Grigi” di Rotzo (Giurassico Inferiore, Altopiano di Asiago) e loro inquadramento nella paleogeografia e nella evoluzione tettonico-sedimentaria delle Prealpi venete. Annali dell'Università di Ferrara (Sezione Scienze Geologiche e Paleontologiche), 5, 1-61.

Bosellini, A., Masetti, D., \& Sarti, M. (1981). A Jurassic "Tongue of the Ocean" infilled with oolitic sands: the Belluno Trough, Venetian Alps, Italy. Marine Geology, 44, 59-95.

Broglio Loriga, C., \& Neri, C. (1976). Aspetti paleobiologici e paleogeografici delle facies "Lithiotis" (Giurese inf.) Rivista Italiana di Paleontologia e Stratigrafia, 82, 651-151.

Castellarin, A., Picotti, V., Cantelli, L., Claps, M., Trombetta, L., Selli, L., \& Carton, A. (2005). Note Illustrative della Carta Geologica D'Italia, foglio 080 Riva del Garda. APAT, Servizio Geologico d'Italia, Firenze, 1-45.

Chaloner, W. G. (1962). Rhaeto-Liassic plants from the Henfield Borehole. Bulletin of the Geological Survey of Great Britain, 19, $16-28$.

Clari, P. (1975). Caratteristiche sedimentologiche e paleontologiche di alcune sezioni dei Calcari Grigi del Veneto. Memorie degli Istituti di Geologia e Mineralogia dell'Università di Padova, 31, 1-63.

Collinson, M. E., Batten, D. J., Scott, A. C., \& Ayonghe, S. N. (1985). Palaeozoic, Mesozoic and contemporaneous megaspores from the Tertiary of Southern England: indicators of sedimentary provenance and ancient vegetation. Journal of the Geological Society, 142, 375 395.

Dal Pozzo, A. (1820). Memorie istoriche dei Sette-Comuni vicentini. Vicenza, Tipografia Paroni: Opera postuma.

Dettmann, M. E. (1986). Early Cretaceous palynoflora of subsurface strata correlative with the Koonwarra Fossil Bed, Victoria. Association of Australasian Palaeontologists, Memoir, 3, 79-110.

De Zigno, A. (1850). Coup d'oeil sur les terrains stratifiés des Alpes Venitiennes. Naturwissenschaftliche Abhandlungen, ser., 1(4), 115.

De Zigno, A. (1852). Sui terreni jurassici delle Alpi Venete e sulla flora fossile che li distingue. Rivista Periodica della Imperiale Reale Accademia delle Scienze di Padova, 1, 1-14.

De Zigno, A. (1856-1868). Flora Fossilis Formationis Oolithicae. Vol. 1. Padova: Tipografia Del Seminario.

De Zigno, A. (1865a). Dichopteris, genus novum filicum fossilium. Monografia del genere Dichopteris, nuovo genere di felce fossile. Memorie dell'Istituto Veneto di Scienze, Lettere ed Arti, 12, 1-16.

De Zigno, A. (1865b). Osservazioni sulle felci fossili dell'Oolite, ed enumerazione delle specie finora rinvenute nei varii piani di quella formazione, coll'aggiunta dei sinonimi, della descrizione dei generi e delle specie nuove, e di un prospetto della loro distribuzione geografica. Rivista Periodica dell'Accademia di Scienze, Lettere ed Arti di Padova, 1864-65, 1-36.

De Zigno, A. (1868). Descrizione di alcune Cicadeacee fossili rinvenute nell'Oolite delle Alpi Venete. Atti dell'Istituto Veneto di Scienze, Lettere ed Arti, 13(3), 1-16.

De Zigno, A. (1872). Sulle piante monocotiledoni e dicotiledoni dell'epoca giurese. Rivista Periodica dell'Accademia di Scienze, Lettere ed Arti di Padova, 1871-72, 1-10.

De Zigno, A. (1873-1885). Flora Fossilis Formationis Oolithicae. Vol. 2. Padova: Tipografia Del Seminario.

De Zigno, A. (1878). Sulla distribuzione geologica e geografica delle conifere fossili. Rivista Periodica della Imperiale Reale
Accademia di Scienze Scienze, Lettere ed Arti di Padova, Padova: Randi Editore.

Feist-Burkhardt, S., Heunisch, C., \& Luppold, F.W. (2009). Überlegungen zur Biostratigraphie und Fazies des "Polyplocus-Sandsteins" (Mittlerer Jura) an der ICE-Trasse östlich Braunschweig. Berliner paläobiologische Abhandlungen, 10, 129-149.

Franceschi, M., Dal Corso, J., Posenato, R., Roghi, G., Masetti, D., \& Jenkyns, H. C. (2014). Early Pliensbachian (Early Jurassic) Cisotope perturbation and the diffusion of the Lithiotis fauna: insights from the western Tethys. Palaeogeography, Palaeoclimatology, Palaeoecology, 410, 255-263.

Fugagnoli, A. (2004). Trophic regimes of benthic foraminiferal assemblages in Lower Jurassic shallow water carbonates from northeastern Italy (Calcari Grigi, Trento Platform, Venetian Prealps). Palaeogeography, Palaeoclimatology, Palaeoecology, 205, 111130.

Fugagnoli, A., \& Loriga Broglio, C. (1998). Revised biostratigraphy of Lower Jurassic shallow water carbonates from Venetian Prealps (Calcari Grigi, Trento Platform, northern Italy). Studi Trentini di Scienze Naturali, Acta Geologica, 73, 65-73.

Grandori, L. (1913a). Intorno alla flora dei Calcari grigi studiata da Achille De Zigno. Atti dell'Accademia Veneto-Trentino-Istriana, 6 , 144-148.

Grandori, L. (1913b). La Flora dei Calcari Grigi del Veneto. Memorie dell'Istituto Geologico della Reale Università di Padova, 2, 1-112.

Grandori, L. (1915). Su di un seme mesozoico di pteridosperma e sulle sue affinità con forme paleozoiche e forme viventi. Atti dell'Accademia Veneto-Trentino-Istriana, 8, 107-116.

Grauvogel-Stamm, L., \& Lugardon, B. (2004). The spores of the Triassic Lycopsid Pleuromeia sternbergii (Münster) Corda: morphology, ultrastructure, phylogenetic implications, and chronostratigraphic inferences. International Journal of Plant Sciences, 165(4), 631-650.

Gry, H. (1969). Megaspores from the Jurassic of the Island of Bornholm, Denmark. Geological Society of Denmark, Bulletin (Meddelelser Fra Dansk Geologisk Forening), 19(1), 69-89.

Harris, T. M. (1961). The Yorkshire Jurassic Flora. I ThalophytaPteridophyta. London: Trustees of the British Museum (Natural History).

Harris, T. M. (1964). The Yorkshire Jurassic Flora. II Caytoniales, Cycadales and Pteridosperms. London: Trustees of the British Museum (Natural History).

Harris, T. M. (1969). The Yorkshire Jurassic Flora. III Bennettitaleans. London: Trustees of the British Museum (Natural History).

Harris, T. M. (1979). The Yorkshire Jurassic Flora. V Coniferales. London: Trustees of the British Museum (Natural History).

Harris, T. M., Millington, W., \& Miller, J. (1974). The Yorkshire Jurassic Flora. IV: 1. Ginkgoales, 2. Czekanowskiales. London: Trustees of the British Museum (Natural History).

Hueber, F. M. (1982). Megaspores and a palynomorph from the Lower Potomac Group in Virginia. Smithsonian Contributions to Paleobiology, 49, 1-69.

Kendall, M. W. (1949). On a new conifer from the Scottish Lias. Annals and Magazine of Natural History, Series 12, 2(16), 299-307.

Koppelhus, E. B., \& Batten, D. J. (1989). Late Cretaceous megaspores from southern Sweden: morphology and paleoenvironmental significance. Palynology, 13, 91-120.

Kovach, W.L. (1994). A review of Mesozoic megaspore ultrastructure. In M. Kurman, J. Doyle (Eds.), Ultrastructure of fossil spores and pollen (pp. 23-35). Kew: Royal Botanic Garden.

Kovach, W. L., \& Batten, D. J. (1989). Worldwide stratigraphic occurrences of Mesozoic and Tertiary megaspores. Palynology, 13, 247277.

Kovach, W. L., \& Batten, D. J. (1993). Diversity changes in lycopsid and aquatic fern megaspores through geologic time. Paleobiology, 19, $28-42$. 
Kozur, V. H. (1973). Neue Megasporen aus dem Karn des Ilek-Beckens. Geologische und Paläontologische Mitteilungen, Innsbruck, 3, 112.

Kustatscher, E., Wachtler, M., \& Van Konijnenburg-van Cittert, J. H. A. (2010). Lycophytes from the Middle Triassic (Anisian) locality Kühwiesenkopf (Monte Prà della Vacca) in the Dolomites (Northern Italy). Palaeontology, 53(3), 595-626.

Kustatscher, E., Donà, H., \& Krings, M. (2015). Sporophyll organization in the Triassic isoetalean lycophyte Lepacyclotes (formerly Annalepis) zeilleri from Germany. Paläontologische Zeitschrift, $89,303-311$

Lund, J. J., \& Pedersen, K. R. (1985). Palynology of the marine Jurassic formations in the Vardekløft ravine, Jameson Land, East Greenland. Geological Society of Denmark, Bulletin, 33, 371-399.

Lundblad, B. (1948). A selaginelloid strobilus from East Greenland (Triassic). Meddelelser fra Dansk Geologisk Forening, 11(3), 351363

Lundblad, B. (1950). On a fossil Selaginella from the Rhaetic Hyllinge, Scania. Svensk Botanisk Tidskrift, 44(3), 477-487.

Marcinkiewicz, T. (1971). The stratigraphy of the Rhaetian and Liasin Poland based on megaspore investigations [Stratygrafia Retyku $i$ Liasu w Polsce na Podstawie badan megasporowych] Prace Instytut Geologiczny (Warsaw), 65, 1-57.

Marcinkiewicz, T. (1978). Megaspore assemblages in the Keuper of Poland. In B. Wodzelewska (Ed.) Stratigraphy of the Keuper in Poland [In B. Wodzelewska (Ed.) Zespoly megasporowe $w$ Kajprze Polski. Stratygrafia Kajpru w Polsce,] (vol. 87, pp. 6184). Prace Instytut Geologiczny.

Marcinkiewicz, T. (1980). Jurassic megaspores from Grojec near Kraków. Acta Palaeobotanica, 21, 37-60.

Masetti, D., Claps, M., Giacometti, A., Lodi, P., \& Pignatti, P. (1998). I Calcari Grigi della Piattaforma di Trento (Lias inferiore e medio, Prealpi Venete). Atti Ticinensi di Scienze della Terra, 40, 139-183.

Masetti, D., Fantoni, R., Romano, R., Sartorio, D., \& Trevisani, E. (2012). Tectonostratigraphic evolution of the Jurassic extensional basin of the eastern southern Alps and Adriatic foreland based on an integrated study of surface and subsurface data. AAPG Bulletin, 96, 2065-2089.

Massalongo, A. (1851). Sopra le piante fossili dei terreni terziari del vicentino. Tipografia A. Bianchi, Padova.

Massalongo, A. (1853a). Plantae fossiles novae in formationibus tertiariis regni veneti nuper inventae. Tipografia Ramanzini, Verona.

Massalongo, A. (1853b). Enumerazione delle piante fossili Miocene fino ad ora conosciute in Italia. Verona: Tipografia G. Antonelli.

Massalongo, A. (1856). Analisi di una lignite scavata nel commune di Badia Calavena nel veronese. Estratto dalla Gazzetta Ufficiale di Verona, Anno II, 77, 1-4.

Massalongo, A. (1859). Specimen photographicum animalium quorumdam plantarumque fossilium Agri Veronensis. A. B. Massalongo descripsit Mauritius Lotze photographice expressit. Tipografia Vicentini Franchini, Verona.

McLoughlin, S., Jansson, I.-M., \& Vajda, V. (2014). Megaspore and microfossil assemblages reveal diverse herbaceous lycophytes in the Australian Early Jurassic flora. Grana, 53(1), 22-53.

Morris, P. H., \& Batten, D. B. (2016). Megaspores and associated palynofloras of Middle Jurassic fluviodeltaic sequences in North Yorkshire and the northern North Sea: a biofacies-based approach to palaeoenvironmental analysis and modelling. Journal of Micropalaeontology, 35, 151-172.

Néraudeau, D., Saint Martin, S., Batten, D. J., Colin, J. P., DavieroGomez, V., Girard, V., Gomez, B., Nohra, Y. A., Polette, F., Platel, J. P., Saint-Martin, J. P., \& Vullo, R. (2016). Palaeontology of the upper Turonian paralic deposits of the Sainte-Mondane Formation, Aquitaine Basin, France. Geologica Acta, 14, 53-69.
Neri, M., Roghi, G., Ragazzi, E., \& Papazzoni, C. A. (2016). First record of Pliensbachian (Lower Jurassic) amber and associated palynoflora from the Monti Lessini (northern Italy). Geobios, 50, 49-63.

Pedersen, K. R., \& Lund, J. J. (1980). Palynology of the plant-bearing to Hettangian Kap Stewart Formation, Scoresby Sund, East Greenland. Review of Palaeobotany and Palynology, 31, 1-69.

Posenato, R., \& Masetti, D. (2012). Environmental control and dynamics of Lower Jurassic bivalve build-ups in the Trento Platform (Southern Alps, Italy). Palaeogeography, Palaeoclimatology, Palaeoecology, 361-362, 1-13.

Potonié, R. (1956). Synopsis of the genera of the sporae dispersae. Part 1 [Synopsis der Gattungen der sporae dispersae. Teil 1]. Beihefte zum Geologischen Jahrbuch, 23, 1-103.

Pott, C., Krings, M., \& Kerp, H. (2008). The Carnian (Late Triassic) flora from Lunz in Lower Austria: palaeoecological considerations. Palaeoworld, 17, 172-182.

Raine, J. I., Mildenhall, D. C. \& Kennedy, E. M. (2011). New Zealand fossil spores and pollen: an illustrated catalogue. GNS Science Miscellaneous Series No. 4. Retrieved from http://data.gns.cri.nz/ sporepollen/index.htm Accessed 12 Aug 2017.

Roghi, G., \& Romano, R. (2008). Gruppo dei Calcari Grigi nei Monti Lessini. La Lessinia-Ieri Oggi Domani, 31, 47-52.

Schulz, E. (1967). Sporenpaläontologische Untersuchungen rätoliassischer Schichten im Zentralteil des Germanischen Beckens. Paläontologische Abhandlungen B, 2(3), 561-562.

Scott, A. C., \& Playford, G. (1985). Early Triassic megaspores from the Rewan Group, Bowen Basin, Queensland. Alcheringa, 9, 297-323.

Singh, C. (1964). Microflora of the Lower Cretaceous Mannville Group, east-central Alberta. Research Council of Alberta, Bulletin, 15, 1 239.

Skog, J. E., \& Hill, C. R. (1992). The Mesozoic herbaceous lycopsids. Annals of the Missouri Botanical Garden, 79, 648-675.

Slater, S. M., \& Wellman, C. H. (2015). A quantitative comparison of dispersed spore/pollen and plant megafossil assemblages from a Middle Jurassic plant bed from Yorkshire, UK. Paleobiology, 41(4), 640-660.

Slater, S. M., \& Wellman, C. H. (2016). Middle Jurassic vegetation dynamics based on quantitative analysis of spore/pollen assemblage from the Ravenscar Group, North Yorkshire, UK. Palaeontology, 59(2), 305-328.

Slater, S. M., Taylor, W. A., Batten, S. D. J., Hill, C. R., \& Wellmann, C. H. (2015). Morphology and wall ultrastructure of a new and highly distinctive megaspore from the Middle Jurassic of Yorkshire, UK. Review of Palaeobotany and Palynology, 216, 33-43.

Srivastava, S. K. (1976). The fossil pollen genus Classopollis. Lethaia, 9 , 437-457.

Taylor, T. N., Taylor, E. L., \& Krings, M. (2009). Paleobotany: the biology and evolution of fossil plants. Amsterdam/New York: Elsevier Science.

Taugourdeau-Lantz, J. (1983). Associations palynologiques definies dans le Trias Languedocien (France) - interpretation stratigraphique. Cahiers de Micropaléontologie, Nouvelle série, 3, 5-20.

Taugourdeau-Lantz, J. (1984). Les associations palynologiques du Trias Languedo dien dans leur Cadre Europeen - Influence du Milieu (Sols de Vegetation-Milieu sedimentaire). Géologie de la France, 1984, 23-28.

Van Erve, A. W. (1977). Palynological investigation in the Lower Jurassic of the Vicentinian Alps (Northeastern Italy). Review of Palaeobotany and Palynology, 23, 1-117.

Van Konijnenburg-van Cittert, J. H. A., Kustatscher, E., Bauer, K., Pott, C., Schmeißner, S., Dütsch, G., \& Krings, M. (2014). A Selaginellites from the Rhaetian of Wüstenwelsberg (Upper Franconia, Germany). Neues Jahrbuch für Geologie Paläontologie, Abhandlungen, 272(2), 115-127.

Van Konijnenburg-van Cittert, J. H. A., Kustatscher, E., Pott, C., Schmeißner, S., Dütsch, G., \& Krings, M. (2016). New data on 
Selaginellites coburgensis from the Rhaetian of Wüstenwelsberg (Upper Franconia, Germany). Neues Jahrbuch für Geologie Paläontologie, Abhandlungen, 280(2), 177-181.

Wesley, A. (1956). Contributions to the knowledge of the flora of the grey limestones of Veneto, Part I. A revision of the Flora Fossilis formationis Oolithicae of De Zigno. Memorie degli Istituti di Geologia e Mineralogia dell'Universita di Padova, 19, 1-69.

Wesley, A. (1958). Contributions to the knowledge of the flora of the grey limestones of Veneto, Part II. A revision of the Flora Fossilis formationis Oolithicae of De Zigno. Memorie degli Istituti di Geologia e Mineralogia dell'Universita di Padova, 21, 1-57.

Wesley, A. (1966). The fossil flora of the grey limestones of Veneto, Northern Italy, and its relationships to the other European floras of similar age. The Palaeobotanist, 14, 124-130.

Wesley, A. (1973). Jurassic plants. In A. Hallam (Ed.), Atlas of palaeobiogeography (pp. 329-338). Amsterdam: Elsevier.

Wesley, A. (1974). On the Bennettitalean remains from the Lias of Northern Italy. In: Symposium on morphological and stratigraphical palaeobotany. Birbal Sahni Institute of Palaeobotany Special Publication (Lucknow, Gumti), 2, 66-72.
Wierer, J. F. (1997). Vergleichende Untersuchungen an Megasporenvergesellschaftungen der alpinen und germanischen Mittel- und Obertrias. Münchner Geowissenschaftliche Abhandlungen, 35, 1-175.

Wierer, J. F. (1999). Megasporen, ein Teilaspekt triassischer Palynologie. In N. Hauschke \& V. Wilde (Eds.), Trias - eine ganz andere Welt. München: Verlag Dr. Friedrich Pfeil.

Winterer, E. L., \& Bosellini, A. (1981). Subsidence and sedimentation on Jurassic Passive Continental Margin, Southern Alps Italy. AAPG Bulletin, 65, 394-421.

Yang, J. (1986). The discovery of Early and Middle Jurassic megaspores from the Junggar Basin, Xingjiang and their stratigraphic significance. In J. Huang (Ed.), Proceedings of the Symposium on Mesozoic and Cenozoic Geology (pp. 207-216). Beijing: Geological Publishing House.

Yang, J. S. (1982). The discovery of Early and Middle Jurassic megaspores from the Junggar Basin, Xinjiang and their stratigraphic significance. Acta Geologica Sinica, 4, 007.

Zavialova, N., Kustatscher, E., \& Van Konijnenburg-van Cittert, J. H. A. (2010). Spore ultrastructure of Selaginellites leonardii and diversity of Selaginellalean spores. Geology of the Alps, 7, 1-17. 